\title{
Research on the Training of Computer Science and Technology Talents in the Era of Big Data
}

\author{
Huang Jian \\ XiJing University, Xi'an 710123, China \\ 565200245@qq.com
}

\begin{abstract}
In order to meet the requirements of the development of computer professional knowledge structure, ability structure and quality education in the era of big data, to conform to the trend of the era of big data of computational thinking, such as the CS2013 of the latest international curriculum system, and to reform existing computer professional talents training plan, this paper explores a new model of innovating the application of computer professional talent training under the era of big data. Through the comprehensive reform of education idea, curriculum system, practice areas, this paper proposes to strengthen training, improve students' practical ability, practical ability, thinking ability and innovation ability, further transform the existing teaching and research resources to improve the quality of personnel training platform and training base, built computer professionals in a distinctive feature of the training for the big data processing field, train innovative high-quality professionals with practical ability and innovative spirit to improve professional employment rate.
\end{abstract}

Keywords-Big data; Talent training; Computer science and technology

\section{INTRODUCTION}

The training mode of talents in Colleges and universities is a product of the concept of education, training objectives, training specifications and training methods of the organic combination of multi levels, it relates to the professional setting, curriculum design, teaching management and quality monitoring a number of education teaching, the key factors in the reform of the pattern of talents training for students, teachers and teaching management etc. in fact, the higher school personnel training mode reform includes two aspects, one is to follow the law of education and external relations, to the social needs as reference, training objectives, training professional setting and professional adjustment of the school to raise the specifications, personnel training to better meet the needs of the society; the two is to follow the internal law of education, have correct educational ideology (including the concept of quality education values, etc.) as the reference datum, adjusting the training objectives, professional training standards, training plan, training The way of raising and coordinating all the elements in the training mode of talent will improve the conformity of the quality of talent training and the goal of talent training ${ }^{[1]}$.

\section{OVERALL PLAN}

Through years of reform and practice of the training mode of Applied Talents in computer specialty, we initially formed the educational concept of "emphasizing both theory and practice, interaction between enterprises and majors, and interaction between students and teachers". According to professional characteristics, adhere to the "School of thought, and strong foundation courses, to build a base and application", careful planning of cultivating the applied talents in Computer Specialty under the era of big data, combining with the students' growth and cultivation of innovative ability, through practice, training, competition, cooperation and other means to practice the application of organic link, promote the combination of theoretical teaching and practical application, to promote research and teaching professional characteristics of back feeding, outstanding service and Western precision agriculture big data applications, to achieve the training goals in students' ability of engineering practice and application innovation center ${ }^{[2]}$. To cultivate advanced application talents with high humanistic quality and innovative spirit and ability.

\section{A. Optimize the curriculum system, strengthen the curriculum requirements, and highlight the characteristics of "universal + special"}

According to the development trend of big data and demand, the research method is to make full use of existing professional teaching and research platform, get enough public knowledge and knowledge of the humanities curriculum in the education of students, reduce the number of professional courses, optimization of structural system of elective courses, professional basic courses, built in professional courses, elective courses, computer curriculum system of general education curriculum supplemented by the public. Highlighting the characteristics of "general plus specialty"[3]. its expertise is mainly reflected in the training of big data analysis engineers, the two is to train big data system development engineers, and the three is to train big data application engineers. 
B. Renew curriculum content, improve teaching quality, establish effective teaching management and quality monitoring system

We will strengthen the teaching practice through engineering practice ability training, add some frontiers knowledge, and integrate engineering application consciousness into teaching. We will select some core courses of professional direction to pilot and gradually extend to other courses. And establish the relevant system of teaching management related and the teaching quality monitoring system, so as to make all the elements of the talent training mode more coordinated ${ }^{[4]}$.

\section{Reform the practice teaching, improve the employment} rate of college students, and build a three level progressive application innovation ability training program

We should adjust the practical training content of innovation practice, optimize the content, and establish a perfect system of practical training course for innovation practice. The three level progressive application innovation ability training program is constructed with "cognitive practice, comprehensive practice and innovation practice" as the main line.

\section{IMPLEMENTATION PLAN}

The project has been implemented for 2 years and is divided into 4 stages:

The first stage: investigation and research, to understand the current teaching situation and students' learning situation, the skills requirements of the graduates, and the training programs of other brothers, and inquire relevant literature. The planned implementation time is 4 months.

The second stage: to develop the training program for applied talents of computer science and technology in the era of large data. According to the results of the investigation and the research results of 6 aspects, a set of effective and feasible teaching, learning, and doing integrated teaching plan is set up for 6 months ${ }^{[5]}$.

The third stage: the training program for Applied Talents in accordance with the planned implementation. The plan is implemented for 5 months.

The fourth stage: To summarize the effect of implementation, to discuss and modify the discussion, and to form a formal training program for applied talents. The plan is implemented for 9 months.

Project implementation schedule:

In July -2017 May 2017, the research plan was drawn up to retrieve the literature and complete the collection and optimization of the related theories.

In August 2017 -2017, October, we carried out the design and implementation of questionnaire analysis and research, summarized the problems existing in the learning process and the actual needs of enterprises.
In November 2017 -2018 January, we analyzed the curriculum group of computer science and technology major, and formulated a professional curriculum system suitable for the training of Applied Talents in the era of big data.

\section{EXPECTED RESULTS}

The first stage: investigation and research, the formation of investigation report and questionnaire survey.

The second stage: the formulation of talent training program to form the application type of computer science and technology in the era of big data

Talent training program.

The third stage: the new talent training model implementation, the formation of practical data analysis report, plan adjustment report.

The fourth stage: To summarize the implementation effect and form a formal training model for professional talents.

\section{SUMMARY}

According to the 2012 Internet Data Center Digital Universe report, global data volumes are up 50\% annually, doubling every two years. It is estimated that by 2020, the total number of global data will reach 35 40ZB, which will increase by more than 20 times in 10 years. The era of big data has come, and the application of big data has attracted more and more attention from all walks of life. Large data analysis and application capabilities have gradually become the core competitiveness of organizations. The effective organization and use of large data will bring unprecedented opportunities for social and economic development. According to the McKinsey Global Research Institute, by 2020, the global talent gap of big data will be as high as 190 thousand. Increased demand for data analysts, data engineers and IT data management specialists has made the industry hot. The Outline of the National Medium and Long-term Education Reform and Development Program (2010-2020) puts forward the requirement of "innovating talent training mode" and "exploring various training modes" to reform the personnel training system. On February 26, 2014, Premier Li Keqiang, at the State Council executive meeting, proposed to focus on employment as a starting point to guide a number of ordinary undergraduate colleges and universities to the national social needs of the University of Applied Science and Technology transformation.

This project closely combines the new demand of modern enterprises for computer science talents under the background of large data, actively responds to the national policy of cultivating applied talents, puts forward the research of "the reform and practice of the cultivation mode of Applied Talents in computer science and Technology Specialty in the era of large data", and analyzes the computer specialty in colleges and universities. On the basis of the problems existing in the existing training mode, we should focus on exploring and researching the key issues such as professional orientation, training objectives, curriculum system and teaching mode. Through the research of this project, we will reform and perfect 
the training mode of applied talents of computer specialty, further enhance students' innovative and practical ability, highlight the characteristics of outstanding engineers training in the era of big data, and push forward the reform of the training mode of applied talents of other undergraduate courses in our university. School plays a role in demonstration and radiation.

\section{REFERENCES}

[1] Tang Weibing, Fu Yuanhai, Wang Zhanxiang. And the transformation of economic growth mode of $[\mathrm{J}]$ technology innovation, economic research,.2014,7:31-42.

[2] Bai Junhong, Chiang Kai Shek. Collaborative innovation, spatial association and regional innovation performance [J], economic research.2015,7:174-187.

[3] Lutong, Party printing. Corporate governance and technological innovation: sub industry comparison [J], economic research.2014,6:115128.

[4] Li Wenlian, Xia Jian Ming. Based on "big data" business model innovation [J], China industrial economy.2013,5:83-95.

[5] Zhu Yongyong. Research on the integration of vocational education skills competition and practice teaching [J], higher engineering education research.2015,5:169-178. 